\title{
New Zealand and the Asia-Europe Meeting
}

\author{
Mathew Doidge \\ National Centre for Research on Europe \\ University of Canterbury \\ Private Bag 4800 \\ Christchurch \\ New Zealand \\ e-mail: mathew.doidge@canterbury.ac.nz \\ DRAFT ONLY - NOT FOR CITATION
}

\begin{abstract}
This article considers New Zealand's accession to the Asia-Europe Meeting, considering both its formal path to membership and the evolving calculus by which its views of the process were structured, focusing on elements such as the enabling context provided by a change of national government in 2008 , the impact of the global financial crisis, and the position of Australia. Drawing on a set of interviews undertaken within the New Zealand Ministry of Foreign Affairs and Trade (MFAT), it goes on to examine perceived benefits of the Asia-Europe Meeting for New Zealand, and the extent to which these have been achieved. Finally, it addresses the issue of a New Zealand ASEM strategy, outlining potential areas for future engagement.
\end{abstract}

Key Words: ASEM; New Zealand; ASEM Membership; NZ-Asia Relations; NZ External Relations

\section{First Order Heading}

Second Order Heading 


\section{Introduction}

In 2010, at its eighth Summit, New Zealand joined the Asia-Europe Meeting process alongside two other new entrants - Australia and Russia - bringing the number of participants to 48 from an initial $26 .{ }^{1}$ New Zealand's path to membership was a long one 15 years from its first expression of interest preceding the inaugural Summit in 1996 until its formal accession. Despite this long timeframe, however, it's accession was in the end something of a rush job, a scramble to respond to events rather than the product of any genuine enthusiasm for the forum. This article examines New Zealand's engagement with ASEM, guided by three core questions: (i) what was New Zealand's path to membership, and what were the key factors underpinning its final decision to join?; (ii) what potential benefits does New Zealand see as stemming from its engagement with the process, and how has it performed in this regard?; and finally (iii) what shape should a New Zealand strategy for engagement with ASEM take?

\section{The Long and Winding Road: New Zealand's Path to Accession}

The issue of extending membership has always been a thorny one for ASEM. One motivation for the European Union's (EU) initial engagement in the process was its exclusion of Myanmar at a time when conflict over its human rights record had effectively hamstrung cooperation in the EU-ASEAN (Association of Southeast Asian Nations) framework. This raised the prospect that future accessions to the Asia-Europe Meeting would be carefully considered and potentially contentious. Further complicating the enlargement issue was the binary nature of the forum, premised upon two groups cohering around particular identities and effectively requiring that new members be demonstrably European or Asian. This was reinforced by early agreement on a 'double key' approach to expansion, with each side selecting its own members subject to approval by all ASEM states.

New Zealand's approach to ASEM membership was tentative at best. In part this stemmed from prior experience. When Malaysian Prime Minister Mahathir Mohamad had proposed an East Asian Economic Caucus (EAEC) in 1990, he had firmly rebuffed expressions of interest from New Zealand and Australia. Consequently, a certain amount of caution on the part of New Zealand's Ministry of Foreign Affairs and Trade (MFAT) was evident in its

\footnotetext{
${ }^{1}$ From ASEM 9 in November 2012, this number increased to 51 with the accession of Bangladesh, Norway and Switzerland.
} 
approach to ASEM (interview with senior MFAT official, May 2012). In the event, such concerns proved to be well-founded. When New Zealand and Australia raised membership prior to the inaugural Summit, the views of Mahathir proved an insurmountable obstacle. While firm support was forthcoming from the European states, Japan, South Korea and the Philippines, opposition from Malaysia and Thailand (Baker 1996, 20; Skelton 1997, 21) meant an effective veto on entry. The key remained Mahathir's opposition which, when filtered through ASEAN's consensus principle, meant that the Association stood as an effective block to any prospect of expanding the forum southwards.

For New Zealand, Mahathir's position led to the shelving of its early ASEM aspirations, a fact reflected in diplomatic communications of the time: 'the key to movement on this issue ... remains Prime Minister Mahathir ... We believe that any chance we might have of gaining some early concession would not be enhanced by more vigorous representation at this stage which [he] might feel compelled to resist, even publicly' (quoted in Rolfe $2005,47-8)$. In short, the potential benefits of ASEM were considered insufficient to outweigh the effort of campaigning for membership. A conscious decision was therefore made to set aside the ASEM issue until the Mahathir problem had been resolved (interview with senior MFAT official, June 2012).

This cost-benefit calculation became more firmly entrenched over the following decade as MFAT's view of the utility of the process gradually dimmed. As is discussed in more detail below, early interest in membership had been conditioned largely by the expectation that ASEM would deliver substantive results, particularly around trade liberalisation, the failure of which to eventuate reinforced the Ministry's resourcing calculus. Indeed, the low priority accorded to the Asia-Europe Meeting is evidenced by its total absence from key MFAT documentation of the period. Thus, for example, the 2007 White Paper Our Future with Asia which established a framework for engagement with the region, urging greater integration into the Asian architecture and highlighting the 'need to be included in the new regional structures that are being put in place' (MFAT 2007, 19), notably excluded ASEM from its consideration. ${ }^{2}$ Further, the sixteen Annual Reports, Statements of Intent, and Briefs to the Incoming Minister published by the Ministry between 2002 and 2010, while routinely emphasising the need to participate in regional structures, completely

\footnotetext{
${ }^{2}$ The focus instead falling on ASEAN, ASEAN+3, APEC and the East Asia Summit.
} 
overlooked ASEM. As a consequence, it was largely Australian efforts that kept the membership issue, even if only intermittently, on the agenda. For MFAT, so long as Australia was also excluded from the process, there was no pressing need for New Zealand to push for accession (interview with former senior MFAT official, April 2012). In effect, responsibility for policy on ASEM membership had been abdicated to the Australian Department of Foreign Affairs and Trade.

The events of 2008/2009 were therefore something of a surprise for MFAT. The Ministry received no warning from their counterparts when, in mid-2008, Australia applied to join ASEM, leaving them 'to some extent, scrambling' (interview of former senior MFAT official, April 2012). The subsequent quick extension of feelers to the European Commission as to the value of New Zealand membership further reinforced the view that MFAT had been wrong-footed by the Australian move and had no real policy in place to cater for the eventuality. In the event, the Ministry resolved to adopt a wait and see approach, with a final decision to be made only when the prospects for Australia's entry were clearer.

The Australian approach to ASEM was itself complicated by the concurrent application of Russia. While substantive objections on the Asian side had largely dissipated after Mahathir left office (interview with Malaysian Foreign Ministry official, June 2012), it was recognised (most notably by Singapore) that the Russian application raised broader issues of membership that would need to be addressed before Australia could be admitted. Russia's Asian credentials were regarded as questionable by the Asian ASEM members, with the case instead being made that it should enter as part of the European grouping. The Europeans in turn argued that membership on their side was restricted to EU member states: that ASEM was, in fact, the Asia-EU Meeting. The compromise reached at the ninth Foreign Ministers' Meeting (FMM) in May 2009 was a 'Temporary Third Grouping', neither European nor Asian, but instead comprised of these leftover states. On this basis, Australian membership was approved.

While New Zealand's membership was not formally addressed at the FMM, informal discussions between Asian and Commission officials suggested that no objections would be raised in principle. However, when New Zealand's application was lodged in September 2009 , it was complicated by the prospect that its wait and see approach may have led it to 'miss the boat' (interview with senior Commission official, July 2011). Indeed, a number of Asian states asserted that membership matters could only be decided by a Foreign 
Ministers' Meeting, which would in effect have placed the application on hold until it could be considered by the tenth FMM in June 2011. New Zealand owed its earlier accession to the action of the Cambodian Ministry of Foreign Affairs and International Cooperation, which argued that approval could be given by Foreign Ministers outside of a scheduled Ministerial Meeting. In practice, and in the face of some opposition, the Cambodian Senior Official on $\mathrm{ASEM}^{3}$ took it upon himself to contact all member state Foreign Ministers by letter, declaring that unless specific objections were raised, assent would be presumed and New Zealand would become a member (interview with former senior MFAT official, April 2012). No formal objections being forthcoming, New Zealand joined as part of the Temporary Third Grouping alongside Australia and Russia at the eighth Summit in 2010.

\section{To Join, or Not to Join? New Zealand's Changing Calculus of Accession}

Setting aside the formal path by which it joined the forum, New Zealand's evolving view of ASEM - from early interest, to subsequent disinterest, and the final volte-face which saw it accede at the eighth Summit - was underpinned by a calculus of accession incorporating a number of elements. As previously noted, intrinsic to the early expression of interest in the ASEM was a set of expectations as to what the process would deliver. A number of factors framed the initial agreement to establish ASEM, structuring many of the expectations as to the role it would perform. For the Europeans, for example, it offered an alternative to the deadlocked dialogue with ASEAN which had been undermined by disagreements over human rights and the membership of Myanmar in the Association. For the Southeast Asians it offered a foundation for increased cooperation and integration within East Asia, making a reality of the earlier EAEC proposal. More significant, however were the motivations relating to addressing a perceived 'missing link' in the global triadic architecture, and concerns about economic marginalisation.

The conception of ASEM as filling a 'missing link' was a key element in Goh Chok Tong's proposal, with a new Asia-Europe dialogue being seen as a necessary complement and balance to existing relationships among the triad of regions, embodied in the EU-US Transatlantic Partnership and in the Asia-Pacific Economic Cooperation (APEC) framework. It was particularly as a mirror to the latter that Goh envisaged ASEM, advocating the creation

\footnotetext{
${ }^{3}$ Acting in his role as one of the two Asian Regional Coordinators.
} 
of 'Pacific-style' ties between the two regions (Pou Serradell 1996, 186). By casting the AsiaEurope Meeting as a mirror and response to APEC, a link was drawn directly between the functioning of Asia-Pacific cooperation and that of the new forum such that APEC'S evolution through the early 1990s played a significant role in framing perceptions about ASEM. While APEC had been operative since 1989, it had only convened its first Summit in 1993, on which occasion it agreed for the first time a set of reciprocal trade concessions. This was followed in 1994 by the tabling of plans for a Pacific Free Trade Area. As a consequence, it was increasingly seen as leaving behind its reputation as a talking shop, pushing instead towards the delivery of substantive results. With the link to ASEM drawn, these initiatives helped to raise clear expectations that the Asia-Europe Meeting too would move rapidly towards the achievement of concrete goals, notably in the area of trade liberalisation.

Alongside the influence of APEC, ASEM was also the product of the economic concerns of its founding members. The EU's reappraisal of its relations with Asia, embodied in the 1994 New Asia Strategy (European Commission 1994), highlighted the centrality of economic matters in its approach to the region, making clear that the primary factor motivating the push for closer relations was concern at missing out on the growth that was occurring there. Similarly, economic priorities were a motivation for the Asian states, and particularly the members of ASEAN concerned with Europe's turn to its eastern neighbourhood and underpinned by perennial fears that the common market was evolving into a fortress. A link with Europe mirroring the economic and commercially focused tie with the United States embodied in APEC was therefore seen as essential (Pou Seradell 1996, 186-8).

Expectations for ASEM were, then, from the outset high. The European Council made this clear when it asserted that the new institution must pursue 'concrete and substantial results' (European Council 1995, 43). While the process was clearly also a political one, the prominence of economic concerns made substantive cooperation in trade and financial matters the primary anticipated outcome of engagement, and indeed this expectation structured the early history of the process. The years following the first Summit saw the establishment of separate Economic and Finance Ministers' Meetings, a Senior Officials' Meeting on Trade and Investment, a Customs Directors-General and Commissioners' Meeting and an Asia-Europe Business Forum, as well as the first steps being taken toward 
the creation of a Trade Facilitation Action Plan (TFAP) and an Investment Promotion Action Plan (IPAP). The launching of the TFAP and IPAP initiatives in particular raised the spectre that institutionalised rules and procedures would emerge to guide the facilitation and liberalisation of Asia-Europe trade and investment relations (Yeo 2003, 155).

Such institutional proliferation quickly became a characteristic of ASEM, reflecting a form of 'cooperation malaise': the creation of new structures was increasingly a substitute for the anticipated substantive engagement. The result has been the increasing breadth of the process, while depth of cooperation has remained limited and substantive outcomes have failed to eventuate. In part this failure has been the product of a capabilityexpectations gap, with anticipated outcomes being premised upon a level of cooperation that has proven beyond the ability of the ASEM partners to achieve (Doidge 2011, 172-4). Additionally, and exacerbating this first difficulty, is the informal nature of cooperation, embodied in the lack of an administrative secretariat, non-binding and consensual decisiontaking, and the preference for soft law instruments. The lack of institutional memory in the form of a secretariat has, for example, meant that meetings under the ASEM umbrella have frequently been characterised by a lack of awareness of the content of prior discussions, and consequently have often ploughed the same turf, impacting the pace of cooperation (interview with Commission official, cited in Doidge 2011, 119), while the non-binding nature of any decisions taken has meant that agreements can be read only as indicative rather than substantive. Given these norms of cooperation, it may be argued that ASEM's structure was from the outset suited more to dialogue than to the delivery of concrete goals.

It is in this context that New Zealand's view of ASEM must be seen. Its early expression of interest was a product of the heightened expectations surrounding the establishment of Asia-Europe cooperation. From the 1990s, issues of trade liberalisation and market access gained particular emphasis in New Zealand's external relations, reflecting both a general cross-party political consensus emergent since the neoliberal turn of the fourth Labour government, ${ }^{4}$ as well as the direction being taken at the global level, embodied for example in the founding of the World Trade Organisation and in the new APEC agenda. New Zealand had signed its first comprehensive Free Trade Agreement in

\footnotetext{
${ }^{4}$ Assumed office in July 1984.
} 
1983 - the Closer Economic Relations (CER) arrangement with Australia - and the establishment of similar frameworks was to become a central feature of its trade strategy over subsequent decades. Alongside this was an increasing strategic focus on Asian markets. ASEM seemed to offer a framework within which a small player like New Zealand could pursue these policy goals effectively. This impetus, however, waned over time: when the process failed to deliver anticipated results, it became devalued in the eyes of MFAT. There was, quite simply, a lack of any sense that ASEM had proved significant, particularly around priority issues for New Zealand (interview with former senior MFAT official, April 2012). Reinforcing this waning enthusiasm for membership was the issue of resourcing, and the calculation that the cost of engaging in the process to the level likely to be expected by other participants was beyond MFAT's capacity to meet (interview with former senior MFAT official, April 2012), an issue that continues to have resonance for New Zealand's engagement.

This calculus clearly changed in $2008 / 2009$, leading ultimately to New Zealand's accession to the process. Three factors were prominent. The first was the enabling context provided by the election of a new government. On the basis of the calculations outlined above, the decision not to pursue membership had become the default setting for the fifth Labour government, in office for the decade from 1999 to 2008 . When it was succeeded by the fifth National government, the inertia of that default position to an extent disappeared (interview with former senior MFAT official, April 2012), with the incoming Foreign Minister - Murray McCully - taking a fresh look at New Zealand's external engagement.

Second, and more importantly, was the changed international circumstance engendered by the global financial crisis, and the apparent impact of this on the ASEM process. Simply, for a brief moment in 2008, ASEM seemed to gain increased relevance and utility in the global context. With the agreement to hold the inaugural G-20 Summit in November of that year to address the crisis, the coincidence of the convening of the seventh ASEM Summit in Beijing in the preceding October lent the process added prominence, comprising as it did ten of the European and Asian G-20 members (including the European Commission) (see Figure 1). ${ }^{5}$ The ASEM Summit therefore became a useful preparatory

\footnotetext{
5 In fact, the first G-20 Summit comprised 22 participants, the Netherlands and Spain being allowed extraordinary presence as representatives of the European Council even though, at that time, France held the rotating Presidency. As such, 12 of the 22 participants were members of ASEM.
} 
forum for the G-20, and indeed was seen to have been particularly beneficial in generating a level of agreement on issues which could potentially have produced stalemate in discussions (e.g. on IMF and World Bank voting reform) (interview with Commission official, cited in Doidge 2011,126$)$. In other words, it was seen as performing something of a clearing house function for the G-20. This seemed to suggest that ASEM was becoming more relevant to global governance, raising the apparent value of forum presence. Indeed it was off the back of the ASEM 7/G-20 concurrence that Australian Prime Minister Kevin Rudd decided to pursue membership. For New Zealand, too, the Beijing Summit was something of a turning point in its perception of the process, raising the prospect that ASEM would build on this experience to become a useful forum for dialogue on matters of substance (interview with senior MFAT official, May 2012). There was therefore a feeling that if such was to be the case, New Zealand needed to be involved (ibid.).

\section{[INSERT FIGURE 1 HERE - LANDSCAPE (CURRENTLY APPENDED TO PAPER)]}

Nevertheless, on its own, this apparent increase in the utility of ASEM was insufficient to reverse New Zealand's stance. It was a third element - the membership of Australia - that constituted the trigger. As previously noted, Australia's position was a significant factor for MFAT - so long as Australia was out, New Zealand's non-membership was no cause for concern. The approval of the Australian application by the 2009 FMM left MFAT facing the prospect that New Zealand would be the only regional state not a member of ASEM, a situation deemed untenable (interview with senior MFAT official, May 2012). Asserted McCully: 'We certainly didn't want to be the only East Asia Summit nation not to be there and that would have been the consequences of not joining' (Young 2010).

Together, these three elements altered the ASEM calculus for New Zealand: with the incoming National government looking afresh at the country's external engagements, with the seventh Summit raising the prospect that the process would evolve in a useful direction, and with Australia's membership application and acceptance, New Zealand accession became a priority for McCully. Nevertheless, this was not a wholehearted endorsement of the forum: rather than on any substantial belief in the efficacy of ASEM, the decision to join was premised upon a wish not to be absent should the process begin to deliver substantive 
outcomes (interview with senior MFAT official, May 2012). It was a defensive response membership as an insurance policy.

\section{New Zealand's Engagement with ASEM}

With its accession to ASEM seen as insurance against potential future significance, rather than the product of a clearly articulated view of the forum's value, there was no expectation on the part of MFAT that New Zealand would be a particularly active player (interview with former senior MFAT official, April 2012). Rather, its touch would be a light one - a flag on the table and not much more (ibid.) - an approach requiring a minimal resource commitment while continuing a tradition in New Zealand foreign policy of keeping a finger in every pie (ibid.). Nevertheless, despite this low level of commitment, and the absence of a coherently structured strategy for engagement beyond the minimum, a number of potential benefits of membership are recognised within MFAT. These fall into two broad areas: (i) dialogue and access; and (ii) reinforcing presence.

\section{ASEM as an Arena for Dialogue and Access}

Despite continuing rhetoric around substantive engagement, the underperformance of ASEM in this respect has generally been recognised. What has become increasingly evident since its inception, however, is a progressive evolution, a transformation in expectations for the dialogue, moving beyond the initial view that the process should deliver 'concrete and substantial results' (European Council 1995, 43) and toward a level of satisfaction with its role as a framework for dialogue without preconceptions. As the structure of ASEM has become progressively more dense, it has gained value in the eyes of participants as a political space, an ideational and discursive process, acting as a framework for dialogue, as a filter for global fora, as an arena for socialization and norm diffusion, and as a mechanism for securitisation (Doidge 2011, 142-3), increasing 'comfort levels' and building trust and understanding among participants (interview with senior MFAT official, June 2012; interview with senior Commission official, July 2011).

ASEM's utility in this respect is recognised within MFAT, with a view that there is benefit in developing a greater understanding of regional perspectives on a variety of issues, and that, in the absence of substantive outcomes, this may prove to be the raison d'être of 
the forum (interview with senior MFAT official, May 2012). Indeed, ASEM's informality fosters this process, providing the space to discuss matters in an open fashion on the understanding that this does not constitute a firm commitment in the global arena. As a consequence, ASEM has proven useful for addressing topics, sometimes of a sensitive nature, which are not considered elsewhere - the Myanmar issue, for example (interview with Malaysian Foreign Ministry official, June 2012). In this respect, Governors' Meetings of the Asia-Europe Foundation (ASEF) have been identified within MFAT as facilitating dialogue on a range of issues in a manner not often seen in other fora (interview with senior MFAT official, June 2012).

Beyond this general process, for New Zealand two specific benefits are identifiable, both of which are related to the expansiveness of the dialogue and its broad membership. The first is the potential use of the forum as a mechanism for addressing priority issues. This could, for example, involve utilising ASEM as a framework through which to identify partners with whom cooperation on global issues may be beneficial (interview with former senior MFAT official, April 2012): as a small player, New Zealand's foreign strategy relies heavily upon the ability to form such coalitions of interest in the broader global system. In addition, however, is the facility for arranging meetings and working groups within ASEM on issues of interest, which may engage a small or large subset of member states, occur in single or multiple iterations, and involve simple information sharing or act as a seed for deeper cooperation (interview with senior Commission official, July 2011). This has been particularly evident under the forum's Social, Cultural and Educational Pillar (the ASEF Pillar), with events addressing labour relations, child welfare, education and so on seen as providing significant value to membership (interview with Malaysia Foreign Ministry official, June 2012).

The second broader benefit is facilitating access to European and Asian leaders and officials, with the opportunity to arrange bilateral, or even minilateral, meetings in the margins of the various ASEM fora. ${ }^{6}$ Most obviously this means gaining access to the larger powers, facilitated by the fact that ASEM is a smaller pond than other fora in which New Zealand is involved (e.g. the UN General Assembly), but it also means engaging smaller and more peripheral (at least as far as New Zealand is concerned) partners. This is seen to be

\footnotetext{
${ }^{6}$ This relates directly, for example, to the Asia White Paper's call to raise the tempo of engagement with Asia through inter alia increased leadership diplomacy (MFAT 2007, 8).
} 
potentially the greatest single benefit of participation (interview with senior MFAT official, May 2012). Multilateral institutions have always been important to New Zealand in this respect, supplementing what is by necessity a limited network of High Commissions and Embassies scattered around the world. Resource constraints mean that MFAT has fewer than 700 offshore staff, spread across 53 delegations, with further cross-accreditations providing a light touch on most states. Among the ASEM membership, MFAT has formal delegations in 23 states (including the European Union) with cross-accreditations to a further 22, while 22 states (including the EU) have embassies in New Zealand with crossaccreditations from a further 21 (see Figure 1). ASEM therefore provides an opportunity to regularly engage with officials from an array of states with which, cross-accreditations notwithstanding, existing relationships are extremely shallow (interview with senior MFAT official, May 2012), allowing MFAT to increase its understanding of these actors and their priorities.

Nevertheless, the potential benefit to be gained by New Zealand in these respects is currently undermined by the low level of its engagement. The previously noted light touch approach to the Asia-Europe Meeting has limited exposure to the ongoing interaction that could make a reality of the dialogue and access elements highlighted. This is a product of the relative level of importance accorded to ASEM when compared to other fora in which New Zealand participates: more significant for reasons of utility and potential economic benefit are APEC and the EAS, while ASEAN and its associated structures remain the priority in Asia as a vehicle for engagement with a number of its primary trading partners (interview with senior MFAT official, May 2012). Here again the resourcing calculation plays its part. With only 1340 staff and a budget of NZ\$500 million (US\$400 million) (Government of New Zealand 2012, 120), MFAT's resources are limited. As a low priority, the resources dedicated to ASEM are correspondingly small - currently only a desk officer in Wellington with parttime responsibility for ASEM matters. While this clearly contrasts with the high resourcing allocated by states such as China and Indonesia (each with a dedicated division within Foreign Affairs) which are actively seeking to exercise influence through the process, a more realistic comparison is the lower but still more significant resourcing of a state such as Malaysia, with two Foreign Affairs officers assigned, and with further ASEM responsible officers within six other Ministries - a perceived necessity given the breadth of the process (interview with Malaysian Foreign Ministry official, June 2012). While seen within MFAT as 
being an appropriate level of resourcing (interview with senior MFAT official, June 2012), such limitations have meant that New Zealand has been a reactive rather than proactive participant (interview with senior MFAT official, May 2012), so far failing to make a significant impact within the process (interview with Malaysia Foreign Ministry official, June 2012).

\section{ASEM as a Tool for Reinforcing Presence}

Beyond these dialogue and access elements, ASEM is seen as a mechanism for reinforcing presence, with two components identifiable. The first involves reinforcing the engagement of key partners in regions of significance to New Zealand. Harking back to the foundation of ASEM itself, for example, is the role of the forum in increasing Europe's presence in Asia, and in particular pushing it to spread its focus beyond China (interview with senior MFAT official, June 2012). In this respect, European soft power engagement, including the contribution of ideas and resources on matters of trade, development and integration, are seen to be an important factor in the future security and stability of the Asian region (ibid.).

The presence issue is also, however, conceived in broader terms, with ASEM seen as a means of bringing European and Asian partners into areas of particular interest to New Zealand. It is a mechanism for cementing the EU not simply into a narrowly defined Asia, but into the wider Asia-Pacific region, and for drawing it and the Asian members further south toward the small island states of the Pacific. Asia-Europe engagement on matters to do with the South Pacific - be it on issues of trade, development, or the environment - is seen to be an important potential outcome of New Zealand's ASEM engagement (ibid.).

The second element is the view that ASEM provides an additional mechanism for reinforcing New Zealand's own presence in Asia, a central goal of its foreign policy strategy. Alongside the EAS, APEC and the various ASEAN fora, the Asia-Europe Meeting provides a means by which New Zealand can demonstrate its Asian credentials (interview with senior MFAT official, June 2012), making a claim to be a part of the broader Asian caucus (rather than an Asian state), fully integrated into the structures of the region (MFAT 2007, 19). This has involved the progressive layering of fora within which New Zealand engages with its Asian partners, either explicitly as part of an Asian grouping (EAS, FEALAC) or in a framework engaging with Asian states (APEC, ASEAN PMC, ASEAN-CER etc.). ASEM is seen as one more piece in this puzzle, further deepening New Zealand's integration into the regional 
architecture (interview with senior MFAT official, May 2012). This aspect, however, was initially somewhat undermined by the membership compromise involved in the establishment of the Temporary Third Grouping. New Zealand, alongside Australia, was a casualty of Russia's application and disagreement over where precisely it should fit. With a solution found at the Senior Officials' Meeting in Copenhagen in March 2012 - with the EU dropping its requirement that the European side comprise only Union member states (opening the path for Norway and Switzerland to accede) as a quid pro quo for Asian acceptance of Russia among their number - the Temporary Third Grouping was dissolved, and New Zealand was folded into the Asian side.

While formal integration into the Asian side was a matter of some significance for New Zealand (interview with senior MFAT official, May 2012), in practice it had already begun to adopt strategies to align itself more clearly with the Asian grouping. In 2011, for example, a decision was made to move responsibility for ASEM from the Asia to the Europe Division within MFAT, thus calibrating the administration of the process with its Asian counterparts. This was based firmly on the view that ASEM provided New Zealand with an opportunity to work closely with the Asian countries, and it therefore made greater sense to have an equivalency of representation within ASEM fora (interview with former senior MFAT official, April 2012). Similarly, efforts were made with regard to participation in the governance of the Asia-Europe Foundation to ensure that New Zealand's regional preferences were clear. From the outset, New Zealand's ASEF Governor caucused with his Asian counterparts, effectively inviting himself to take part so as to allow no assumption to emerge other than that New Zealand should be a member of the Asian grouping (interview with senior MFAT official, June 2012). For New Zealand, then, its formal incorporation alongside its Asian partners was simply the final destination on a path down which it had already been moving.

Beyond the membership and forum layering aspect of integration into the Asian region is the demonstration of credibility: showing New Zealand to be a serious, committed and vitally engaged participant in the regional architecture (interview with senior MFAT official, May 2012). In the absence of an Asian identity, this is a way to establish the legitimacy of its presence in Asian fora and initiatives, helping to inculcate both a view that it has something to contribute, and a sense that its own interests and those of Asia are intertwined, two elements highlighted prominently in the 2007 Asia White Paper (MFAT 
$2007,6)$. Stated one former MFAT official closely involved in the accession process: 'If we are to establish and register ourselves as being serious about wanting to build links, and build membership and participation in an Asian forum, we have to be willing to accept that sometimes this will take us into organisations and into spaces which are Asian priorities, even if they are not necessarily New Zealand priorities' (interview with former senior MFAT official, April 2012). Indeed, it was such engagement with the region that meant that New Zealand's (and Australia's) accession to ASEM in 2010 was viewed far more positively by Asian states than was that of Russia (interview with Malaysian Foreign Ministry official, 12 June 2012).

Nevertheless, New Zealand's subsequent performance within the process has done little to reinforce the view that it is a serious and committed partner. The eighth Summit in October 2010 provided the first opportunity to engage with forum members at the highest level and, notwithstanding attendance at some prior officials' meetings, constituted in effect New Zealand's formal debut in ASEM. Prior to the Summit, while never declaring Prime Minister John Key's non-attendance, MFAT was careful to avoid committing to his presence (interview with former senior MFAT official, April 2012). Such caution notwithstanding, when Key did not appear at the meeting, with New Zealand instead represented by Deputy Prime Minister Bill English and Foreign Minister Murray McCully, questions were raised as to its commitment to the process. ${ }^{7}$ Indeed, Key's absence led a number of Asian states to raise the possibility of a rule requiring new members to attend their first Summit at the Head of State or Government level, with one representative going so far as to suggest that the accession of new members be put on hold until such time as they were able to do so (interview with senior Commission official, July 2011). Questions as to the seriousness of commitment were further reinforced when the Foreign Minister failed to attend the tenth FMM in Hungary in June 2011 - the first convened since New Zealand's accession - and, despite criticisms of his earlier non-appearance, Prime Minister John Key was again absent from the ninth Summit in November 2012. While such non-attendance has been acknowledged internally to be 'a bit odd' (interview with senior MFAT official, May 2012), it

\footnotetext{
${ }^{7}$ John Key's non-attendance provided a particularly stark contrast to the involvement of Australian Prime Minister Julia Gillard, who used the Summit as an opportunity to engage with a number of leaders, including a first meeting with Chinese Premier Wen Jiabao.
} 
is also a clear indicator of the level of importance of ASEM within the hierarchy of New Zealand engagement with Asia and Europe.

\section{'Suck It and See': Conclusion and Recommendations}

New Zealand's approach to the ASEM process has therefore been underwhelming. Fifteen years after its initial expression of interest, New Zealand was finally accepted into the AsiaEurope Meeting, but with no clear sense of the value of the process or strategy for engagement. Rather, its membership was an insurance policy against potential marginalisation should the forum eventually grow wings. Nevertheless, potential benefits of membership are recognised within the MFAT, even if they are not necessarily actively pursued. ASEM is seen: (i) as a means for addressing priority issues for New Zealand, and for gaining access to leaders and officials; and (ii) as a mechanism for reinforcing its engagement with the Asian region, demonstrating itself to be a serious and committed partner. Its performance in each of these areas has, however, been somewhat lacking, a consequence largely of the resourcing issue: with ASEM low on the list of regional priorities, there is no sense that the allocation of scarce resources will deliver sufficient results. Nevertheless, these elements can be seen as constituting a bare-bones framework on which to found a more proactive New Zealand strategy, one in which it demonstrates its commitment and resolve to the Asian region while pursuing specific priorities in a manner ideally light on resources. Two areas can be identified:

1. Increasing participation; and

2. Defining and engaging in priority areas where a contribution can be made or benefit gained.

As an underlying requisite, New Zealand must engage more. If it is to gain any benefit from ASEM, and if it is to portray itself to be a 'serious and committed' participant, it must at a very basic level be involved. There are various ways this can be achieved. The most obvious is to attend fora at the senior level, at least some of the time. An ongoing bugbear for the Asian states is the relatively low level of representation at key ASEM meetings - the Summit and the FMM - particularly of European states. For the Asians, attendance at the appropriate level is an indicator of commitment to the process, and to relations between the regions (interview with Malaysian Foreign Ministry official, June 
2012). Beyond this, however, if New Zealand is to gain the benefit of access to key leaders in the margins of Summits, it needs itself to be there at the appropriate level.

Setting aside the issue of official representation, an emphasis on ASEF involvement is a simple and cost-effective mechanism for engaging with the process, putting as it does emphasis on the involvement of institutions other than MFAT. New Zealand is an active participant in the ASEF Board of Governors, and punches above its weight in terms of the resourcing of the Foundation, providing SG\$100,000 (US\$82,000) per year in financing (ASEF 2011) - the sixteenth highest amount among the ASEM membership, and a significantly larger contribution than that of Australia, for example, a fact that has not gone unnoticed (interview with senior MFAT official, June 2012). ${ }^{8}$ ASEF itself is a forum for intellectual, cultural and people-to-people engagement, and therefore provides a structured mechanism through which to help make a reality of the Asia White Paper's call for 'more New Zealanders who are confident in their dealings with Asia and Asian societies, [which] will only come through greater familiarity and knowledge of the region and its peoples' (MFAT 2007, 45). More therefore needs to be done to apprise, in particular, New Zealand secondary and tertiary education institutions and relevant civil society organisations of the opportunities available under the ASEF umbrella which can foster new, or support existing, engagement with the Asian region.

To a certain extent, the bread and butter of ASEM engagement is the formulation of initiatives, the establishment of meetings and working groups to address priority issues for member states. It is in this framework that the ideational and discursive aspects of ASEM that are increasingly highlighted take place. New Zealand engagement in such structures has, however, been low, and it has so far not proposed any new initiative, ${ }^{9}$ a consequence of its reactive rather than proactive approach. While resourcing limitations mean that New Zealand is unlikely ever to be a major participant in such structures, one or two priority areas may be manageable. And indeed there are a range of issues that would seem ripe for engagement, and for which involvement could usefully extend beyond MFAT to other

\footnotetext{
${ }^{8} \mathrm{New}$ Zealand began contributing to ASEF in 2010. Australia began contributing in 2011 at a rate of SG\$76,615 (US\$62,000) per year (ranking twenty-third on the list). Figures are for 2011.

${ }^{9}$ A matter noted by other ASEM partners, and identified as an area where improved performance would be welcome (interview with senior Commission official, July 2011; interview with Malaysian Foreign Ministry official, June 2012).
} 
Ministries or stakeholders (thus, to an extent, defraying costs). Two areas in particular can be identified: (i) education; and (ii) Pacific development.

In 2011, New Zealand hosted more than 97,000 foreign fee-paying students at its secondary and tertiary institutions, ${ }^{10} 70$ per cent from its Asian and 9 per cent from its European ASEM partners, generating more than NZ\$730 million (US\$600 million) for the education sector (MinEdu 2012). ASEM therefore offers a significant opportunity to engage collectively with countries accounting for more than three quarters of foreign students on matters of education. And indeed, the ASEM framework has a history of dialogue on education matters, be this through the ASEM Education Ministers' Meeting held annually since 2008, ${ }^{11}$ ongoing seminars on Quality Assurance in Higher Education, or the range of fora targeting matters such as cooperation between the University and business sectors. For New Zealand, issues such as quality assurance in feeder states are an important element in recruiting foreign students to postgraduate study, as is ensuring the recognition of New Zealand's own qualification framework, particularly as it relates to private education providers such as language schools. Additionally, ASEM may provide the opportunity to address issues of priority to the New Zealand education sector including, for example, the provision of offshore education services, a core element in its international education strategy (see e.g. MinEdu 2011). Encouraging the participation of the Ministry of Education could therefore be a useful mechanism both for increasing engagement without drawing heavily on MFAT resources, and for addressing priority issues around New Zealand's international education strategy.

Secondly, ASEM may be useful as a mechanism for addressing New Zealand's regional concerns around the issue of development. ASEM is a constructed reality, and the enlargement of its Asian caucus has, to an extent, involved a progressive redefinition of the region, at least as far as engagement with Europe is concerned. This has involved a transformation from an Asia of great powers and Tiger economies, to one increasingly inclusive of developing countries, and it is this transformation that has seen the issue of development emerge on to the forum's agenda (Holland and Doidge 2012, 176). Development was addressed in detail for the first time at the sixth Summit in 2006 (a noted

\footnotetext{
${ }^{10}$ Of these, 16 per cent are in secondary education providers, 31 per cent in Universities, and 53 per cent in other tertiary education providers (English language schools etc.).

${ }^{11}$ A New Zealand representative attended the third Education Ministers' Meeting in Copenhagen in 2011.
} 
change from the rhetorical statements of earlier meetings), with an ASEM Development Conference subsequently convened in 2009, demonstrating an awareness at the least of the need to engage with the issue.

Nevertheless, while its importance has been recognised, development still remains relatively under-considered, leaving significant space to introduce issues onto the agenda that are of specific interest to ASEM members. One such example, from the New Zealand perspective, is that of Pacific development. ASEM incorporates six of the top seven donors of foreign aid to the Pacific, ${ }^{12}$ including China, the aid programme of which has been the subject of considerable debate among other donors and the broader development community. The role of China in the Pacific has been an object of increasing concern for the governments of New Zealand and Australia, and more recently also the US and the European Union, particularly around the nature of projects funded and the provision of soft loans (see e.g. McCully's comments in AFP 2011, or those of Key in Trevett 2012). ASEM could therefore provide a useful umbrella under which to engage regional donors, pushing if not for the alignment of developmental approaches, at least for some level of agreement on regional development priorities, and in particular working towards the establishment of multinational development projects incorporating China alongside other donors. And indeed New Zealand has something to offer in this area, having in August 2012 agreed a joint project with China for a reticulated water mains system in the Cook Islands (Xinhua News Agency 2012), the first such cooperative undertaking. ASEM therefore provides a potential framework through which New Zealand can both draw the attention of its Asian partners further southwards, and position itself as a bridge between Europe, Asia and the Pacific on issues of development (see Pacific priorities outlined in MFAT 2011, 7). ${ }^{13}$

With all of that said, the future role of New Zealand in the Asia-Europe Meeting remains uncertain. As has been outlined, it seems at least feasible that New Zealand can develop a clearer and more active strategy for engagement while maintaining a relatively light touch from the Ministry of Foreign Affairs and Trade. Setting aside the issue of attendance at Summits and Foreign Ministers' Meetings, this involves encouraging and

\footnotetext{
12 The top seven aid donors to the nations of the Pacific Islands Forum are, in order: Australia, US, China, Japan, New Zealand, European Commission and France (Hanson and Fifita 2011, 5).

${ }^{13}$ Such a bridging role might also be extended to include the US, Secretary of State Hillary Clinton having highlighted New Zealand-China cooperation as a good example for the United States (Radio New Zealand News 2012).
} 
facilitating the engagement of other actors in the broader ASEM process, thus to an extent lifting some of the burden from MFAT itself. From a base level of fostering people-to-people engagement through ASEF, to the more complex process of identifying priority issues and facilitating the participation of relevant Ministries in Wellington, there are a range of options open to the Ministry of Foreign Affairs and Trade. What will largely determine New Zealand's level of engagement, however, is the performance of ASEM itself, and its ability to deliver substantive cooperation. Ultimately, therefore, when it comes to New Zealand's role in the Asia-Europe Meeting, as one MFAT official commented, 'we'll just have to suck it and see' (interview with senior MFAT official, June 2012). 


\section{Acknowledgements}

The research for this paper was enabled by the grant of a New Zealand European Union Centres Network (EUCN) Research Award. Special thanks also go to those officials in New Zealand, Europe and Asia who generously agreed to be interviewed.

\section{References}

AFP (2011) NZ questions China's Pacific aid strategy. New Zealand Herald, 13 July. http://www.nzherald.co.nz/nz/news/article.cfm?c_id=1\&objectid=10738288. Accessed 20 February 2013.

ASEF (2011) 48 Members, One Vision: Annual Report 2011. Singapore, Asia-Europe Foundation.

Baker M (1996) Malaysia acts to bar Australia's entry to EU-Asia summits. The Age, 4 March:20.

Doidge M (2011) The European Union and Interregionalism: Patterns of Engagement. Farnham, Ashgate.

European Commission (1994) Towards a New Asia Strategy. COM (1994) 314 final.

European Council (1995) Madrid European Council: Conclusions of the Presidency. Bull Eur Union 12:9-51.

Government of New Zealand (2012) The Estimates of Appropriations for the Government of New Zealand for the Year Ending 30 June 2013 [Budget 2012]. Wellington, New Zealand Treasury.

Hanson F, Fifita, M (2011) China in the Pacific: The New Banker in Town. Sydney, Lowy $\begin{array}{llll}\text { Institute for International Policy. } & \text { for }\end{array}$ http://lowyinstitute.cachefly.net/files/pubfiles/Hanson_and_Fifita\%2C_China_in_the _Pacific_web.pdf. Accessed 20 February 2013.

Holland M, Doidge M (2012) Development Policy of the European Union. Basingstoke, Palgrave Macmillan.

MFAT (2007) Our Future with Asia. White Paper. Wellington, Ministry of Foreign Affairs and Trade.

MFAT (2011) Briefing for Incoming Ministers. Wellington, Ministry of Foreign Affairs and Trade. 
MinEdu (2011) Leadership Statement for International Education. Wellington, Ministry of Education.

http://www.minedu.govt.nz/ /media/MinEdu/Files/EducationSectors/InternationalE ducation/PolicyStrategy/LeadershipStatement2011.pdf. Accessed 20 February 2013.

MinEdu (2012) Export Education Levy Full Year 2003-2011. Wellington, Ministry of Education.

http://www.educationcounts.govt.nz/_data/assets/excel_doc/0019/102592/Export -Education-Levy-Full-Year-2003-to-2011.xls. Accessed 20 February 2013.

Pou Serradell V (1996) The Asia-Europe Meeting (ASEM): A Historical Turning Point in Relations Between the Two Regions. Eur Foreign Aff Rev 1(2):185-210.

Radio New Zealand News (2012) US to follow NZ's lead on China in the Pacific - Clinton, $\begin{array}{llll}\text { Radio New } & \text { Zealand }\end{array}$ http://www.radionz.co.nz/news/world/114763/us-to-follow-nz\%27s-lead-on-chinain-the-pacific-clinton. Accessed 20 February 2013.

Rolfe J (2005) Coming to Terms with the Regional Identity. In Smith AL (ed) Southeast Asia and New Zealand: A History of Regional and Bilateral Relations. Singapore, Institute of Southeast Asian Studies, pp 32-56.

Skelton R (1997) Our Asian ally. The Age, 25 April:21.

Trevett C (2012) Combine your aid programmes with ours, Key hints to China. New Zealand Herald, 30 August. http://www.nzherald.co.nz/politics/news/article.cfm?c_id=280\&objectid=10830409. Accessed 20 February 2013.

Xinhua News Agency (2012) China-NZ joint Pacific aid project targets water in Cook Islands. Xinhua News Agency, 30 August. http://news.xinhuanet.com/english/china/201208/31/c_131820178.htm. Accessed 20 February 2013.

Yeo LH (2003) Asia and Europe: The Development and Different Dimensions of ASEM. London, Routledge.

Young A (2010) NZ joins powerful EU-Asia forum. New Zealand Herald, 23 August. http://www.nzherald.co.nz/politics/news/article.cfm?c_id=280\&objectid=10668185. Accessed 20 February 2013. 
Figure 1: New Zealand in Asia: Forum (and selected FTA) Membership, and Diplomatic Representation

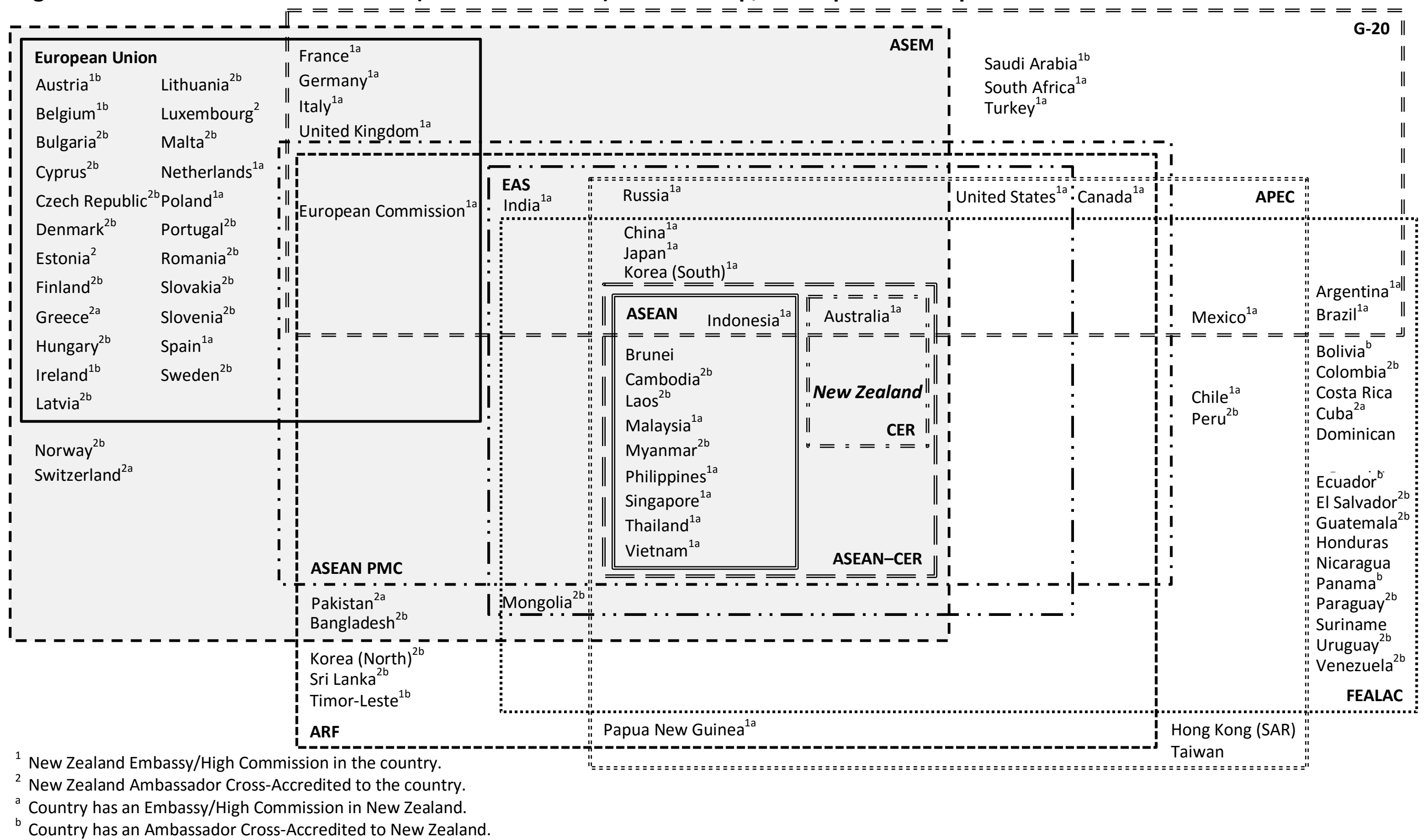

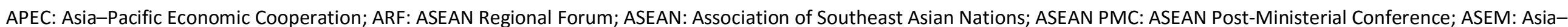
Europe Meeting; CER: Closer Economic Relations; EAS: East Asia Summit; FEALAC: Forum for East Asia-Latin America Cooperation; G-20: Group of 20 Developed Countries. 